平成 4 年レーザー学会学術講演会第12回年次大会

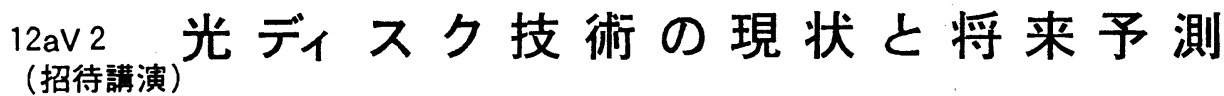

\section{東海大学 開発工学部情報通信工学科}

後 藤 顯 也

\section{1. はじめに}

光ディスクシステムの原型は1973年にK. Compaan らが発表したアナログパルス記録 によるビデオディスク (VD)プレーヤである。初期のコヒーレント光源としては $\mathrm{He}-\mathrm{Ne}$ レーザーが搭載されていたが光ティスクファイル装置, コンパクトディスク (CD) プレ 一ヤ，VDプレーヤ， CD-ROMドライブ，コンピュータメモリ用ディスクドライブなど現 在ではすべて半導体レーザー (LD)に置き代えられている。LDは小型・軽量・安価・長 寿命であり，空間コヒーレンスを劣化させずにノイズに関係する時間コヒーレンスの みを容易に劣化させることができるという優れた特性をもっている。

光ディクシステムのキーコンポネントは光ティスクと光へッドである。光ヘッド は半導体レーザー光をその発振波長入で決まる絞込み限界（回折限界）まで細く収束 し，サブミクロンサイズの情報ピット列を光ディスク媒体に記録したり，光ディスク 上に記録されたその情報ピット列を非接触的に読み出す機能を有している。そのため に光ヘッドには半導体レーザーダイオード, レーザービーム整形光学系, 送受光分離 のための偏光ビームスプリッター，フォーカスエラー検出光学系，トラッキングエラ 一検出光学系, フォーカス制御アクチュエータ, トラッキング制御アクチュエータ, 1. $2 \mathrm{~mm}$ 厚の光ディスク基板を透してレーザービームを使用波長の回折限界によって決 まる $1 \mu \mathrm{m}$ 以下の微小サイズに収束させる高開口数（高NA）の対物レンズ，再生信号 檢出光学系などが搭載されている。

光ディスクシステムを小型軽量にするために最近のへッドでは内臓部品の小型軽量 化がはかられており，なかでも，記録済トラック検出のためのへッドアクセス時間の 短縮化には光学素子の微小化と小型軽量複合化技術が必須である。他の用途用の光学 部品に比べて光ディスク用微小光学素子では許容される光学部品の幾何学的波面収差, すなわち光学部品の設計製造上の面精度不備による収差発生がとくに厳しく制限され る。ここでは光ディスクヘッド技術の現状と今後の開発動向について述べる。

\section{2. 光ディスクドライブの種類と特改}

光ディスクシステムには民生用情報機器として, CDプレーヤと光VDプレーヤの他に パソコンを内蔵した対話型光ディスクプレーヤCD-I（Interactive），CD-R（商品名） ディスクに一回だけCD方式で記録可能な記録再生型CD-Rプレーヤの登場が予定されて いる。さらに, 直径6.4 cmの書換型光磁気 (Hagneto Optical:M0)ディスクを利用した 音楽の記録・再生・再記録用のミニディスク (MD)の本年末発壳も計画されている。

産業用情報機器として追加記録(Write Once Read Many :WORM, 追記型) 方式と書換 
平成 4 年レーザー学会学術講演会第12回年次大会

可能(Re-Writable : 書換型) 万式の光ディスクドライブおよびこれらの方式と再生専 用 (ROM) 方式とを兼ねた方式のドライブがある。具体的には，大容量ファイルメモリ 装置用8 12" のWORMディスクドライブ，パソコン(PC)およびワークステーション(WS) 向け5. 25 3. 5" のRe-Mritable ディスクドライブや5. 25" WORMドライブ, PS・WS用の 再生専用CD-ROMディスクドライブ, さらにWORMとROM や Re-WritableとCD-ROMとが 1 枚のディスクに内在したPartial ROM 光ディスクドライブなどが実用化され, あるい は実用化されようとしている。

光ティスクプレーヤや光ドライブに共通するシステム特有の技術を抽出すると：

（1）回折限界に収束したLDビームを使用し，1.2 1. $5 \mathrm{~mm}$ 厚の透明ディスク基板を通し て光ディスク情報ピット面へ情報の出し入れを行う

（2）開口数（Numerical Aperture:NA)の大きな対物レンズを使用し，半導体レーザー ビームをレンズのNAと波長で定まる回折限界で制限される最も細いビームウエスト

(ビーム径)に収束させている

（3）ディスク基板成形上の面精度・形状バラッキ，ディスク交換の際の対物レンズ焦 点位置の変動や回転に伴うディスク面振れによる焦点位置変動を自動補正するため にェ1 $1 \mu \mathrm{m}$ の精度でレーザービームウエスト位置（焦点）を制御するアクチュエータ と焦点位置誤差を光学的に検出する機能とを内臓している

（4）幅 $0.5 \mu \mathrm{m}$ のピット列（トラック）上へ 上0. $1 \mu \mathrm{m}$ の精度でレーザービームウエスト を追従制御させたり，光ディスクの形状中心と回転中心との間の偏心を補正制御す るトラッキング制御用アクチュエータとトラックとレーザーの焦点の相対位置誤差 を検出する機能とを内臓している

（5）レーザービームを光ディスクの所定のトラックへアクセスするためのへッド位置 決め制御機能を内蔵している

（6）アナログパルス信号再生用 VD の場合にはディスク回転ムラによる信号の時間軸 ズレを電気的に補正する機能を具備している

（7）コンピュータ周辺機器用のドライブでは高速シーク技術が必須であり，高速アク セス時の急速なヘッド停止に伴う対物レンズの首振り運動が発生する。目的のトラ ック検出とともに対物レンズの瞬時位置を検出する機能を持っている などである。

これら民生用および産業用の光ディスクシステムに共通する心臟部は光ディスク媒 体と光へッドとであるが,ここでは後者の光へッドに関してのみ少し詳しく述べる。

前述したように, 光ヘッドの光学部品には(1)刘物レンズ (OL), (2)コリメータレンズ (CL), (3)ビーム・スプリッタ (BS)や偏光ビームスプリッタ (PBS), (4)レーザービーム 断面形状の整形や非点収差の補正用の光学素子, (5) $1 / 4$ 波長板 (QWP)，(6)対物レンズ の焦点位置誤差を検出するための非点収差発坐用円筒レンズ (CYL) やフーコプリズム, (7)トラッキング誤差検出用の回折格子(GT)などがある。この他に(8)焦点制御アクチュ エータ, (9)ラック（ラジアル）制御アクチュエータなどのサーボ・メカトロニクス 部品や対物レンズ位置検出機能, さらに(10半導体レーザー (LD)や多分割光検出器 (PD) 等の電子デバイスなど磁気ディスクに比し極めて多くの部品で構成されている。 
平成 4 年レーザー学会学術講演会第12回年次大会

\section{3. 光ヘッド基本光学系と波面収差}

レーザー光をその発振波長で決まる回折限界まで絞り込むには，半導体レーザーか ら射出される球面波ビームの波面を出来るだけ乱さずにディスク情報ピット面へ伝え なければならない。すなわちへッド光学系のうちLDから光Diskまでの送光用光学部品 全体の波面収差のrms(Root Mean Square) 值をある制限条件以下に制約しなければな らない。この制限とは光ビームの中心の強度の $80 \%$ に仿下する周辺の範囲までを許容 できるとすることから生じるNaréchel の Criterion（ $\delta \omega)_{\mathrm{mc}}$ が一般に適用される。

簡単な計算からこの值は約 $0.07 \lambda$ と求まる。送光用光学部品全体の波面収差という ことは光へッドを構成する各々の光学部品と光ディスク基板そのものの波面収差, 光 ヘッドへ刘物レンズを設置する際の調整シロに対応する波面収差の劣化分までを含め た送光々学系全部の波面収差の根二乗平均 $(\mathrm{rms})$ であり,これを $(\delta \omega)_{\mathrm{Mc}} \mathrm{c}$ 与えられる 上述許容最大波面収差以下にキープしなければ回折限界で制限される極限の細いビー ムウエストにはできない。LDからDiskまでの光へッド送光用光学部品の各許容最大波

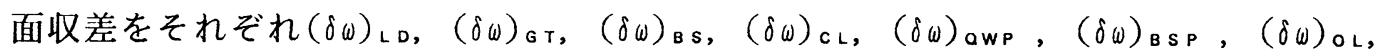
$(\delta \omega)_{\mathrm{D} \text { sc }}$ で表すと Waréchel Criterion は次の (1) 式で与えられる。

$$
(\delta \omega)_{\mathrm{Mc}} \leqq \lambda / 14=0.0714 \lambda
$$

ここで, 送光々学系全体の波面収差 $(\delta \omega)_{M c}$ は用途別へッドによって異なり, 比較的 単純構成である CD 用の場合でも(2) 式となる：

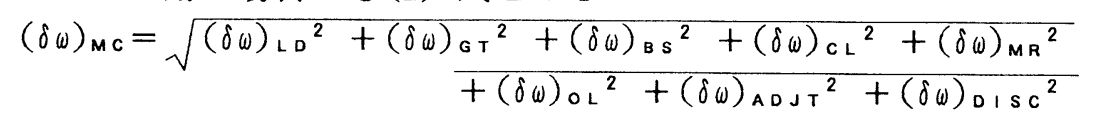

1982年秋から市販されたCDの規格書としてのRed Bookにはディスク基盤の許容最大 波面収差として $(\delta \omega)_{0}$ o s c $=0.05 \lambda$ 相当が与えられている。光ティスクヘッドメーカー

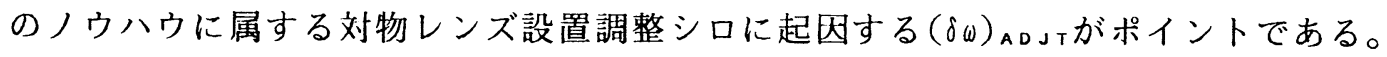
すなわち対物レンズをへッドに取付ける際の角度䛊差がコマ収差発生の原因となるの でヘッド組立て工程の歩留まりを上げるために許容取付け角度を大きく取っておく必 要がある。これを $0.025 \lambda$ とすると，全体で $(\delta \omega)_{M C} \leqq 0.0714 \lambda$ を達成するには各光学 部品の許容最大波面収差 $(\delta \omega)$ を厳しく制限しなければならない。

平板回折格子, ビーム・スプリッ夕，反射ミラー（MR）など平面で成る光部品は比較

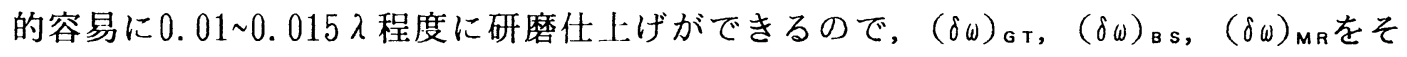
れぞれ $0.012 \lambda ， \quad 0.015 \lambda ， 0.013 \lambda$ とする。しかしコリメータレンズと対物レンズ は平面でないので波面収差が大きい。（1），(2）式を満足させるにはそれぞれの許容波

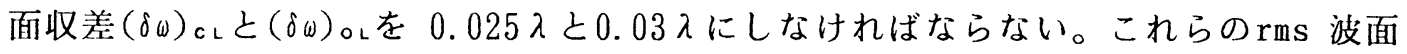
収差值を上式に入れると, 全体で $(\delta \omega)_{M}$ cが $0.072 \lambda$ となり目標に近づく。目標の波面 収差よりも大きいとディスク再生の際にビットエラー発生頻度が高くなる。

\section{4. 収束レーザービーム}

再生用光へッドは対物レンズから射出されたレーザービームをディスクに記録され た幅 $0.5 \mu \mathrm{m}$ で長さ $0.5 \mu \mathrm{m}$ (CD用の場合は0.9 3.3 $\mu \mathrm{m}$ ) 前後の微小ピット列に照射し 1. 4 1.6 $\mu \mathrm{m}$ のピット列（トラック）間隔の記録情報を追跡し, ピット情報を正確に 
平成 4 年レーザー学会学術講演会第12回年次大会

検出する使命を持つ。そのためにレーザービームサイズをトラック左右方向（ラジア ル方向）で $2.0 \mu \mathrm{m}\left(1 / \mathrm{e}^{2}\right)$,トラック進行方向で $1.7 \mu \mathrm{m}\left(1 / \mathrm{e}^{2}\right)$ 以下に細く絞らな ければならない。波長を $\lambda$, 対物レンズの開口数を $\mathrm{NA}$ で表すとレーザービーム中心 部強度の $1 / \mathrm{e}^{2}$ に強度が低くなるレーザービーム外周直径（ビームウエスト） $\omega$ は

$$
\omega=\mathrm{K} \cdot \lambda / \mathrm{NA}
$$

で与えられる。ここで定数 $\mathrm{K}$ は対物レンズへの入射光束の光量振幅分布が均等のとき には0.96であり, 光量振幅分布がガウス分布で表されるときには1.34の值をとる。こ れらのことから波長が短く, 光量振幅分布が均等に近くカットしたビームを使用する ROM ディスク用ヘッドではNA $\geqq 0.45$, 波長が長くガウス光量振幅分布レーザービーム をカットせずに用いるWORHおよびRe-writable ディスクではNA 20.053 が必要となる。

\section{5. 対物レンズアクチュエータ}

$1.7 \mu \mathrm{m}\left(1 / \mathrm{e}^{2}\right)$ 程度に収束されたLDビームウエストを光ディスクの情報記録面の ラジアル方向に $\pm 0.1 \mu \mathrm{m}$, 焦点深度方向に $\leqq \pm 1 \mu \mathrm{m}$ と高精度制御するために対物レンズ アクチュエータが必要である。高精度であるばかりでなく制御範囲がそれぞれ 400 , $\pm 1000 \mu \mathrm{m}$ と広い $(30 \sim 35 \mathrm{~dB})$ ので制御に $\mathrm{E} / 0, \mathrm{~A} / 0$ 素子が使用できない。経済的に実現 できる方法は今のところ磁界中に置いたコイルに電流を流して生ずる電磁力を利用す る方法しかない。可動部質量, ダンパの弾性材料制動係数, バネ定数, 駆動力, 变位, コイル巻数, コイル駆動有効長, 作用有効磁束密度, コイル電流から入力電流 $\mathrm{I}(\mathrm{s})$ に よるアクチュエータ変位X(s)に対する伝達関数 $G(\mathrm{~s})$ が求まる。G(s)をグラフで示した ものがBODE線図であり，図中に現れる高次共振周波数を除去したり光ディスクの動作 より高い周波数に追い込むのがアクチュエータ技術のポイントである。部品材料を高 剛性，軽量化，対称構造化に設計するのが対策技術の一つである。

\section{6. 次世代の光ヘッド}

以上, 現状の光ヘッド設計の光学系とアクチュエータ設計の概要とポイントとを述 ベた。光ディスクシステムは大記録容量, 記録の長寿命, ディスク交換可能など磁気 ティスクシステムに比べて多くの長所を持っているが, 光学系が複雑でへッドの可動 部質量が大のためへッドアクセス時間が長く，また磁気へッドに比較して高価である。 ROM ディスクヘッドの代表であるCDへッドですら製造単価がミ¥1. $5 \mathrm{k}$ もしている。

WORM, Re-writable用も含めHDD やFDD に対抗するODD を生む目的のために光導波路 型対物レンズやヘッドが研究されてきたが, 単価はむしろ従来型より高価になりそう である。また上述した電磁方式のアクチュエータと併用しなければならず，IIDD 並の 光ヘッドアクセス時間の短縮もできない。光導波路への結合損失や光導波路損失の問 題, それに回折型レンズの狭視野角の問題もある。M0信号検出光学系のみの集積光学 化素子は今後とも生かされるであろうが, 光へッド全体を光導波路型にする集積光学 化へッドは成功しない。HDD やFDD に対抗するODD として筆者が数年前から提案して いるICI Digital paper など光フロッピーディスクを応用したレンズレス, ティスク 交換可能，かつベルヌーイ方式の自動焦点機能をもつ格安な方式のヘッドが生れよう。 